\title{
STUDY ON THE ACCUMULATION OF COPPER FROM SOIL TO BIOMASS OF SOME VEGETABLES
}

\section{Le Thi Thanh Trana*, Nguyen Van Haa, Nguyen Mong Sinh ${ }^{\mathrm{b}}$, Nguyen Ngoc Tuanc \\ ${ }^{a}$ The Faculty of Chemistry, Dalat University, Lamdong, Vietnam \\ ${ }^{b}$ Lamdong Union of Science and Technology Associations, Lamdong, Vietnam \\ ${ }^{c}$ Nuclear Research Institute, Lamdong, Vietnam}

\author{
Article history \\ Received: April $11^{\text {th }}, 2016$ \\ Received in revised form ( $\left.1^{\text {st }}\right)$ : June $28^{\text {th }}, 2016 \mid$ Received in revised form $\left(2^{\text {nd }}\right)$ : July $28^{\text {th }}, 2016$ \\ Accepted: August $28^{\text {th }}, 2016$
}

\begin{abstract}
In this study, the accumulation of copper from soil to biomass of spinach, lettuce, carrot and potato was investigated. The results of this work showed that the absorption of copper from soil to these plants depended on biological features of each plant and thus, might be usefully applicable in agricultural cultivation of the mentioned plants.
\end{abstract}

Keywords: Accumulation of copper; Carrot; Copper-polluted soil; Lettuce; Potato; Spinach.

\section{INTRODUCTION}

Daniel (1964) documented that Sommer is the first scientist to clearly demonstrate that copper is an essential micronutrient for plants. This element activates some enzymes in plants which are involved in lignin synthesis. It is also essential in several other enzyme systems including those that are required in the process of photosynthesis, in plant respiration, and in plant metabolism of carbohydrates and proteins (Daniel, 1964). Daniel (1964) showed that copper played an important role in synthetic and metabolic processes of gluxide, phosphatide, nucleprotide and protide. Furthermore, this metal actively involved in many stages of exchange nitrogen denitrification, such as free nitrogen assimilation and protide synthesis (Yruela, 2005). Thus, in the course of farming, we should supply copper with appropriate levels to ensure the optimize growth and development of plants. However, the supplement with high concentration of copper can cause some adverse effects on the growth of plants.

\footnotetext{
${ }^{*}$ Corresponding author: Email: tranltt@ dlu.edu.vn
} 
Excess copper in the growing medium can restrict root growth by burning the root tips and thereby causing excess lateral root growth. Study of Marschner (1995) showed that at high levels, copper can compete with iron and sometimes molybdenum or zinc in plant uptake of these metals. For humans, copper is extraordinarily useful in biological systems. It is involved in many biochemical processes that support life and required for a host of physiological functions including normal immune function, sexual function, neurosensory functions such as cognition and vision. But the most common effects associated with long-term, excessive copper intakes have included sideroblastic anamenia, hypochromic microcytic anaemia, leukopenia, lymphadenopathy, neutropenia, hypocupraemia and hypoferrae-mia (Angelova, Asenova, Nedkova, \& Koleva, 2011). When using agricultural products that contain high levels of copper, human can be intoxicated through the food chain.

In this paper, we describe the accumulation of copper from soil to plants and recommend limitation for the addition of this essential element in farming at suitable dose to ensure the growth of the plant but not harmful to consumer health.

\section{MATERIALS AND METHODS}

\subsection{Materials}

\subsubsection{Equipment and instruments}

- Shimadzu Atomic Absorption Spectrometry AAS - 7000 Series with hollow cathode lamps of $\mathrm{Cu} ; \lambda_{\mathrm{Cu}}=324, .64 \mathrm{~nm}$.

- $\quad$ Compressed air and Ar gas systems.

- Drying oven.

- $\quad$ Fisher Science Electric stove, Germany.

- Satorius Analytical Balance measures masses to within $10^{-5} \mathrm{~g}$, Germany.

- $\mathrm{pH}$ meter. 
- $\quad$ Beakers, hoppers, erlenmeyer flasks, volumetric flasks, graduated cylinders; Germany.

- $\quad$ Pipets, micropipets; England.

\subsubsection{Chemicals}

- $\quad \mathrm{HNO}_{3} 65 \%(\mathrm{~d}=1.35 \mathrm{~g} / \mathrm{ml}), \mathrm{HclO}_{4} 70 \%(\mathrm{~d}=1.75 \mathrm{~g} / \mathrm{ml})$; Merck.

- $\mathrm{Cu}\left(\mathrm{NO}_{3}\right)_{2} .3 \mathrm{H}_{2} \mathrm{O}$, Kanto Chemical Co., Japan.

- Standard solutions are prepared by serial dilution of single element standard purchased from vendors that provide traceability to National Institute of Standards and Technology (NIST) standards.

\subsection{Methods}

\subsubsection{Field experiment}

The soil used in this experiment was topsoil $(0-20 \mathrm{~cm})$ collected from an uncontaminated vegetable field in Ward 8, Dalat City. The result of soil analysis clearly exhibited that copper content in this soil was below the safe limits $(42.78 \pm 3.04 \mathrm{mg} / \mathrm{kg}$ dried soil).

The soil was air-dried, passed through $2 \mathrm{~mm}$ sieve and different copper doses were added by spraying $\mathrm{Cu}\left(\mathrm{NO}_{3}\right)_{2}$ solutions. Fifteen kilograms of the prepared soil were placed in each pot for growing lettuce and spinach while the amount of this soil in each pot for growing carrot and potato was twenty five kilograms.

Empirical model included three areas:

- The research model of accumulation of copper from soil to plants: these plants were grown under cultivation mode as in reality, but copper at different amounts was added to the soil used.

- Control experiment: these vegetables were grown under the same conditions as models mentioned above in soil without adding copper. 


\subsubsection{Planting and caring plants}

The seeds of carrot were germinated in plastic trays and the seedlings were transplanted after two weeks into individual pots. The seedlings of spinach, lettuce and potato were bought from seedling farms. These plants were grown under cultivation mode which was defined by Department of Agriculture and Rural Development, Lamdong province. These plants were watered twice a day, maintaining a relative humidity about $65 \%$. About 13 to 15 days after being cultivated, weak or dead plants were eliminated, and only the well-developed plants were left with the density of 6 plants/spot for spinach and lettuce, 2 plants/spot for potato and 10 plants/spot for carrot. Mature plants (after 45 days for spinach and lettuce, 105 days for potato and carrot) were harvested at the same time.

\subsection{Plant sampling and analysis}

At the end of the growth period, the plants were carefully removed from the soil. The leaves and roots were washed carefully and dried separately at $60^{\circ} \mathrm{C}$ in a drying oven to constant weight. The dried leaf and root samples were homogenized separately in a porcelain mortar. The homogenized samples were digested by a mixture of $\left(\mathrm{HNO}_{3}\right.$ $(25 \mathrm{~mL})$ and $\mathrm{HClO}_{4}(10 \mathrm{~mL})((\mathrm{AOAC}), 1995)$. The clear digested liquid was filtered through filter paper and the contents of copper in the filtrate were determined using the flame atomic absorption spectrophotometer (F-AAS).

\section{RESULTS AND DISCUSSIONS}

The results obtained from the research model of accumulation of copper from soil to plants showed that copper was a cumulative metal. When we increased its amounts in soil, the levels of its hoards in examining vegetables were increased. The obtained copper contents in edible parts of lettuce, spinach, carrot and potato grown in copper-added soils are presented in Table 1 and Table 2.

Examinations showed that in every case the copper concentration found in the soil exceeded those measured in the biomass of these examined plants. Copper exists in many forms in soils, among them free $\mathrm{Cu}^{2+}$ activity is considered to be the best indicator 
of phytoavailability. Free $\mathrm{Cu}^{2+}$ concentration of soil solution is generally extremely low because more than $98 \%$ of copper in solution bound to soluble organic matter at neutral pH (Sauve, McBride, Norvell, \& Hendershot, 1997). Thus, the concentration of copper accumulated in the biomass of plants was lower than this element's content in soil.

Table 1. Concentration of $\mathrm{Cu}^{2+}$ in copper-added soil and in biomass of lettuce and spinach grown in this soil

\begin{tabular}{ccccc}
\hline \multirow{2}{*}{$\begin{array}{c}\text { Concentration of } \\
\mathrm{Cu}^{2+} \text { in soil }\end{array}$} & \multicolumn{3}{c}{ Concentration of $\mathrm{Cu}^{2+}$ in biomass of spinach and lettuce $(\mathrm{mg} / \mathrm{kg}$ fresh vegetable) } \\
\cline { 2 - 5 }$(\mathrm{mg} / \mathrm{kg}$ of dried soil $)$ & Shoot & Root & Shoot & Root \\
\cline { 2 - 5 } & $4.3 \pm 0.3$ & $7.2 \pm 0.5$ & $3.8 \pm 0.2$ & $5.5 \pm 0.4$ \\
100 & $5.8 \pm 0.4$ & $8.3 \pm 0.8$ & $4.5 \pm 0.3$ & $5.7 \pm 0.3$ \\
200 & $6.2 \pm 0.4$ & $12.4 \pm 0.7$ & $5.0 \pm 0.2$ & $6.4 \pm 0.3$ \\
300 & $8.5 \pm 0.7$ & $13.1 \pm 1.0$ & $6.5 \pm 0.5$ & $7.5 \pm 0.5$ \\
400 & $8.0 \pm 0.5$ & $11.9 \pm 0.7$ & $6.8 \pm 0.4$ & $8.0 \pm 0.5$ \\
600 & $9.1 \pm 0.7$ & $13.7 \pm 0.9$ & $6.9 \pm 0.4$ & $8.7 \pm 0.4$ \\
800 & $12.4 \pm 0.8$ & $16.9 \pm 1.2$ & $7.3 \pm 0.4$ & $8.9 \pm 0.4$ \\
1000 & $15.7 \pm 1.2$ & $17.3 \pm 1.5$ & $7.0 \pm 0.4$ & $8.5 \pm 0.7$ \\
1200 & $16.2 \pm 1.0$ & $21.5 \pm 1.2$ & $7.6 \pm 0.6$ & $9.3 \pm 0.6$ \\
1500 & $17.8 \pm 0.8$ & $22.9 \pm 1.6$ & $7.1 \pm 0.5$ & $9.2 \pm 0.4$ \\
\hline
\end{tabular}

In addition, the absorption and accumulation of copper from soil to plants depended on biological features of each plant. When copper content in soil was 50 $\mathrm{mg} / \mathrm{kg}$, this metal concentration was in order of root of carrot $<$ root of potato $<$ shoot of lettuce $<$ shoot of spinach < root of lettuce < shoot of potato < shoot of carrot $<$ root of spinach. At higher concentration of copper in soil, this order was changed. However for tuber vegetables (carrot and potato), the content of copper accumulated in the shoots was extremely higher than that in the roots.

Specifically, the copper content accumulated in the shoots of carrot was 1.8 times higher than that in the roots of carrot. These results harmonize with Kádár (1995) statements that carrot root is genetically more protected against the harmful element accumulation; Mainly leaves can accumulate the microelements to a toxic degree. Similarly, the copper content in the shoot of potato was 2.1 times higher than that in the root of this plant. In contrast, for leafly vegetables (spinach and lettuce), the concentration of copper accumulated in the root was higher than that in the shoot. On average, the copper content in the root of lettuce was 1.3 times higher than that in the 
shoot. Among these plants, lettuce has the accumulative capacity of metals inside its parts at a relatively high rate, which increases in the root and gradually decreases during the translocation to the shoot (Peijnenburg, Fang, Shu, \& Barcelo, 2000). The similar comment was proposed from the analytical results of copper accumulated in spinach biomass. On average, the copper content in root was 1.5 times higher than that in shoot of this plant. According to Cook, Kostidou, Vardaka, and Lanaras (1997), for herbaceous vegetables, copper accumulated in roots was higher than that in the aboveground parts (leaves, stems, branches flowers, fruits, nuts, ...). This difference can be explained by the selective transport of metal ions in the plant. In particular, the decline of mobility of copper between the xylem toleration when absorbed into the roots and the retention in libe (phloem) during transport to the parts on the ground can reduce the amount of copper transported from the root to the stem and leaf of the plant. Marschner (1995) reported that, for leafy vegetables, copper tended to accumulate in root tissue, so only a small amount of this metal was transported to stems and leaves. Thus, each plant has the ability to absorb and accumulate copper with varying degree.

\section{Table 2. Concentration of $\mathrm{Cu}^{2+}$ in copper-added soil and in biomass of carrot and} potato grown in this soil

\begin{tabular}{ccccc}
\hline \multirow{2}{*}{$\begin{array}{c}\text { Concentration of } \\
\mathrm{Cu}^{2+} \text { in soil }\end{array}$} & \multicolumn{3}{c}{ Concentration of $\mathrm{Cu}^{2+}$ in biomass of spinach and lettuce (mg/kg fresh vegetable) } \\
\cline { 2 - 5 }$(\mathrm{mg} / \mathrm{kg}$ of dried soil $)$ & \multicolumn{3}{c}{ Carrot } & \multicolumn{3}{c}{ Potato } \\
\cline { 2 - 5 } & Shoot & Root & Shoot & Root \\
\hline 50 & $6.1 \pm 0.4$ & $2.3 \pm 0.2$ & $5.9 \pm 0.5$ & $2.6 \pm 0.2$ \\
100 & $6.3 \pm 0.4$ & $2.5 \pm 0.2$ & $7.2 \pm 0.5$ & $3.1 \pm 0.2$ \\
200 & $6.9 \pm 0.4$ & $3.8 \pm 0.2$ & $8.1 \pm 0.6$ & $3.9 \pm 0.2$ \\
300 & $8.1 \pm 0.5$ & $4.1 \pm 0.3$ & $9.7 \pm 0.6$ & $4.7 \pm 0.3$ \\
400 & $8.2 \pm 0.4$ & $5.2 \pm 0.3$ & $10.3 \pm 0.6$ & $5.3 \pm 0.4$ \\
600 & $9.4 \pm 0.7$ & $5.4 \pm 0.4$ & $10.7 \pm 0.8$ & $5.8 \pm 0.4$ \\
800 & $9.5 \pm 0.8$ & $6.2 \pm 0.5$ & $10.9 \pm 0.8$ & $6.3 \pm 0.5$ \\
1000 & $9.9 \pm 0.8$ & $6.5 \pm 0.6$ & $10.5 \pm 0.9$ & $6.7 \pm 0.6$ \\
1200 & $9.6 \pm 0.9$ & $6.4 \pm 0.5$ & plant died \\
1500 & plant died & plant died & plant died \\
\hline
\end{tabular}

In addition, the analytical results of copper content in these vegetables biomass also allowed identifying the absorption limit of this element for each type of vegetables. For carrots, the absorption limit was $600 \mathrm{mg} / \mathrm{kg}$ of copper in soil. For potatoes, at 1200 $\mathrm{mg} / \mathrm{kg}$ or higher concentration of copper in soil, plants could not survive and develop. 
For lettuce, the absorption limit was $600 \mathrm{mg} / \mathrm{kg}$ of copper in soil; from this level or higher content of copper in soil, this kind of plant could still grow well in polluted environment but copper accumulated in the biomass did not significantly change. However, for spinach, the adsorption limit of copper was not identified although the empirical model was implemented at $1500 \mathrm{mg} / \mathrm{kg}$ of this element in soil. Thus, the analytical results combined with the recorded rate of growth of four vegetables during the crop showed that carrot and potato adapted worse than lettuce and spinach in copper added soil at the same high level. Potatoes and carrots could not grow in $1500 \mathrm{mg} / \mathrm{kg}$ copper polluted soil. Meanwhile, the leafy vegetables, i.e. lettuce and spinach could still grow in this soil. These results proved that each kind of plant with different physiology characteristics could adapt to a polluted environment at different levels.

\section{CONCLUSION}

This study aimed to investigate the mass distribution of copper from soil to vegetables (spinach, lettuce, carrot and potato) cultivated in compost soils at different levels of this metal contamination. It was found that, copper concentration in these plants depended on the concentration of this metal in the soil in which the plants were grown, i.e. the accumulated copper content in the plants was increased when-higher levels of this metal contamination in the soil were applied. The absorption and accumulation of copper from soil to plants depended on biological features of each plant. For tuber vegetables (carrot and potato), the content of copper accumulated in shoots was extremely higher than this element concentration in roots. In contrast, for leafly vegetables (spinach and lettuce), the concentration of copper accumulated in root was higher than its content in shoot. Besides, the analytical results of copper content in these vegetable biomasses also allowed identifying the absorption limit of copper in each type of vegetables. For carrot, the absorption limit was $600 \mathrm{mg} / \mathrm{kg}$ of copper in soil; for potatoes, $1200 \mathrm{mg} / \mathrm{kg}$ of copper in soil; and for lettuce, $600 \mathrm{mg} / \mathrm{kg}$ of copper in soil. However, for spinach, the absorption limit of copper was not identified.

\section{REFERENCES}

(AOAC), A. O. A. C. (1995). Official method of analysis, 16th ed. AOAC International: Arlington, VA, USA. 
Angelova, M., Asenova, S., Nedkova, V., \& Koleva, R. (2011). Copper in the human organism. Trakia Journal of Sciences, 91, 88-98.

Cook, C., Kostidou, A., Vardaka, E., \& Lanaras, T. (1997). Effects of copper on the growth, photosynthesis and nutrient concentrations of Phaseolus plants. Photosynthetica, 34, 179-193.

Daniel, F. J. (1964). Algae and man. New York: Plenum Press.

Kádár, I. (1995). Contamination of the soil-plant-animal-human food chain with chemical elements in Hungary. Környezetés természetvédelmi kutatások, Budapest, 30, 388-395.

Marschner, H. (1995). Mineral nutrition of higher plants. London: Academic Press.

Peijnenburg, W., Fang, G., Shu, W. H., \& Barcelo, J. (2000). Quantification of metal bioavailability for lettuce (Lactuca sativaL.) in field soils. Arch Environ Contam Toxicol, 39, 420-430.

Sauve, S., McBride, M. B., Norvell, W. A., \& Hendershot, W. H. (1997). Copper solubility and speciation of in situ contaminated soils: Effects of copper level, pH and organic matter. Water Air Soil Poll., 100, 133-149.

Yruela, I. (2005). Copper in plants. J. Plant. Physiol., 17(1), 145-156.

\title{
NGHIÊN CÚ̉U MÚ̉C ĐỘ TÍCH LŨY CỦA ĐỒNG TỬ ĐẤT TRỒNG LÊN SINH KHỐI MỘT SỐ LOẠI RAU
}

\author{
Lê Thị Thanh Trân ${ }^{a^{*}}$, Nguyễn Văn Hậ, Nguyễn Mộng Sinh ${ }^{b}$, Nguyễn Ngọc Tuânc \\ ${ }^{a}$ Khoa Hóa học, Truờng Đại học Đà Lạt, Lâm Đồng, Việt Nam \\ ${ }^{b}$ Liên hiệp các Hội Khoa học Kỹ thuật tỉnh Lâm Đồng, Lâm Đồng, Việt Nam \\ ${ }^{c}$ Viện Nghiên cứu Hạt nhân, Lâm Đồng, Việt Nam \\ "Tác giả liên hệ: Email: tranltt@dlu.edu.vn \\ Lịch sử bài báo \\ Nhận ngày 11 tháng 04 năm 2016 \\ Chỉnh sửa lần 01 ngày 28 tháng 06 năm 2016 | Chỉnh sửa lần 02 ngày 28 tháng 07 năm 2016 \\ Chấp nhận đăng ngày 28 tháng 08 năm 2016
}

\section{Tóm tắt}

Trong nghiên cứu này, sư tích lũy của đồng tù đất lên sinh khối một số loại rau, bao gồm bó xôi, xà lách mṍ, khoai tây, cà rốt đã được xác định. Kết quả nghiên cứu cho thấy, mỗi loại rau có khả năng hấp thu và tích lũy đồng tù đất trồng với mức độ khác nhau tùy thuộc vào đặc điểm sinh lý và do vây, điều này cần được luu ý trong việc lựa chọn loại cây trồng phù hơp trong canh tác.

Từ khóa: Bó xôi; Cà rốt; Khoai tây; Ô nhiễm đồng trong đất; Sự tích lũy của đồng; Xà lách mõ. 